
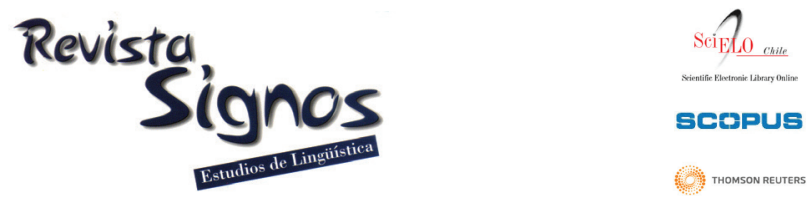

\title{
A case study of building and animal metaphors in specialized discourse: Are scholars' metaphorical conceptualizations represented in discourse?
}

Un estudio de caso de las metáforas de construcción y de animales en el discurso especializado: ¿Están las conceptualizaciones metafóricas de los académicos representadas en el discurso?

\author{
Hanna Skorczynska \\ Universidad Politécnica de Valencia \\ ESPAÑA \\ hskorczy@idm.upv.es
}

Recibido: 02-III-2013 / Aceptado: 03-III-2014

\begin{abstract}
This study provides corpus-based evidence for the claim that metaphorical conceptualizations postulated by scholars in a particular discipline are expressed in specialized discourse. Scholars often propose alternative metaphors to address particular issues, and these metaphors may become more or less linguistically productive in specialized discourse. This corpus-based study looks into project management discourse to find evidence of two conceptual metaphors, proposed by scholars to enhance the understanding and management of real-life projects. The Chinese wall metaphor (Angling, 1988) was first postulated to depict situations in which several projects are managed simultaneously in a stone wall building-like manner. The alternative Chinese dragon metaphor (Eskerod, 1996) was later proposed to highlight the complexity and unpredictability of multi-project management. This study follows Philip's (2010) method to identify conceptual metaphors or metaphor themes in specialized discourse. The corpus of nearly 400,000 words used in this study included research papers as well as periodical journal articles. The results show a higher frequency and a broader range of metaphorical expressions for the animal theme, including the Chinese dragon metaphor. The study discusses how metaphorbased theoretical claims are reflected in specialized discourse and the consequences for management practices.
\end{abstract}

Key Words: Metaphor, specialized discourse, building metaphor, animal metaphor. 


\section{Resumen}

Este estudio aporta pruebas basadas en los datos de corpus sobre cómo las conceptualizaciones metafóricas postuladas por los académicos en una disciplina encuentran su expresión en el discurso especializado. Los académicos a menudo proponen aproximaciones teóricas alternativas para afrontar problemáticas concretas. Estas aproximaciones pueden llegar a ser más o menos productivas a nivel lingüístico en el discurso especializado. En este trabajo se analiza el discurso sobre la gestión de proyectos para buscar evidencias del uso de las metáforas conceptuales que en su momento fueron propuestas por los académicos para mejorar el entendimiento y la gestión de los proyectos reales. La metáfora de la muralla china (Angling, 1988) fue postulada para describir las situaciones en las que se gestionan simultáneamente varios proyectos de una manera similar a la construcción de un muro. La alternativa metáfora del dragón chino (Eskerod, 1996) fue lanzada para realzar la complejidad de la gestión de proyectos múltiples. El estudio siguió el método de Philip (2010) para identificar las metáforas conceptuales o temas metafóricos en el discurso especializado. Un corpus de aproximadamente 400.000 palabras que incluye artículos de investigación, así como los artículos de revistas profesionales fue creado para este estudio. Los resultados obtenidos muestran los usos más frecuentes y expresiones metafóricas más variadas correspondientes al tema metafórico de animales, incluyendo la metáfora del dragón chino. El estudio comenta como las reivindicaciones basadas en metáforas se reflejan en el discurso especializado y sus consecuencias para la práctica empresarial.

Palabras Clave: Metáfora, discurso especializado, metáfora de construcción, metáfora de animal.

\section{INTRODUCTION}

Metaphorical conceptualizations, as postulated by scholars in a discipline, can be envisioned as theoretical approaches to particular issues and problems, and these might be reflected in the discipline's discourse with varying consistency. Some may be more successful in terms of scientific reliability than others, and be more productive in coining metaphor-based terms and expressions in real language use. No study, to the best of my knowledge, has examined whether the successful or predominant metaphorical conceptualizations are actually productive linguistically, or whether the metaphorical expressions in the specialized discourse of a particular discipline have arisen from other less dominant metaphorical conceptualizations.

In this research, the metaphor-based theoretical views on managing projects will be contrasted with the real language use in the project management discipline. Even though the use of metaphor in project management has not attracted much attention from scholars and practitioners, two papers (Angling, 1988; Eskerod, 1996) proposed specific metaphors to better understand and manage projects in multi-project environments. The metaphor of the Chinese wall and the metaphor of the Chinese dragon focus on contrasting aspects of managing projects: the former 
highlights order and predictability, while the latter, constant change and dynamism. These two opposing conceptualizations of projects provide different views on project management practices, and may have implications for business management, as well as for linguistic representation in discourse.

In this study, the search for discourse evidence of conceptual metaphors proposed in the literature is different from methods commonly used for metaphor identification in corpora (Deignan, 2005). Unlike other techniques consisting basically in manually examining corpus samples for metaphor key words, and further computer-assisted corpus analyses, in this study the data for metaphorical expressions were obtained in a top-down manner, that is, by searching the entire corpus for the lexical items used metaphorically in the discipline.

The study follows Philip's (2010) method to identify conceptual metaphors or metaphorical themes in specialized corpora. The advantage of this method is that metaphorical expressions are examined in their combined uses with the corpus key words, thereby ensuring that the corpus topic metaphors are indeed identified and analyzed. This is especially important when analyzing a sample of specialized discourse, as the metaphorical expressions related with the subject of the discipline must be filtered out. The quantitative data obtained in this study were treated statistically and serve to confirm the existence of the metaphorical linguistic expressions related with the two conceptual metaphors in discourse.

\section{Metaphors in the discipline of project management}

Metaphors play an essential role in formulating and articulating scientific theories (Kuhn, 1979; Bicchieri, 1989; Boyd, 1993). Boyd (1993) distinguished between theoryconstitutive metaphors, used by scientists to express theoretical claims when there is no adequate literal paraphrase for them, and others, such as heuristic and exegetical metaphors, which are more common in the case of mature sciences. Heuristic metaphors allow scientists to begin the enquiry of a phenomenon without implying any causal relationship between the domains involved. They are a "pre-analytic cognitive act", (Schumpeter, 1954: 41), which may develop into a scientific theory, as was the case of the human capital metaphor in economics proposed by T. P. Schultz. Exegetical or pedagogical metaphors are used ad hoc to teach or explain theories with available non-metaphorical formulations, and have no further implications for the development of the discipline. In the present study, the Great Wall metaphor (Angling, 1988) and the Chinese dragon metaphor (Eskerod, 1996) seem to be exegetical. Nevertheless, they may also serve heuristic functions, as they give novel perspectives to problems in multiple project management, which in turn allows for the identification of appropriate solutions.

From the perspective of theory change in mature sciences, metaphors were considered as crucial to establish links between the real world and scientific language, 
as they provide new ways to understand and express natural phenomena. Theory change is usually paralleled by a change in some of the relevant metaphors used, and thus, metaphors do not only assist in structuring theories, but they also provide a linguistic extension of these (Bicchieri, 1989). Metaphors are used to introduce theoretical terminology where none previously existed, fulfilling the function of catachresis. Boyd (1993: 483) argued that:

"the use of metaphor is one of many devices available to the scientific community to accomplish the task of accommodation of language to the causal structure of the world".

Despite a large number of studies which have looked into the use of metaphor in economic and business discourse (e.g. Henderson, 1994; Charteris-Black \& Ennis, 2001; Charteris-Black \& Musolff, 2003; Herrera-Soler \& White, 2012), few have examined the use of metaphor in project management discourse. The research conducted so far has revealed that building metaphors are generally more frequent in project management discourse than in general business discourse (Skorczynska, 2010). Further research (Skorczynska, 2012) also showed that building, journey and nautical metaphors generate different cognitive constructs and distinct metaphorical expressions in project management discourse in comparison to general business discourse. Both these studies indicate that metaphor assists in the changes produced by the dynamics of knowledge specialization both at the conceptual and discourse levels.

The discipline of project management deals with directing and coordinating human and material resources throughout the life cycle of a given project using modern management techniques to achieve predetermined objectives of scope, cost, time, quality, and participant satisfaction (PMI Standards Committee, 2008). A project is a temporary endeavour with a clearly defined goal. Unlike routine management activities continually carried out by organizations, managing a project implies undertaking new tasks, never attempted in the past and not likely to be repeated in the future (Kerzner, 2004). These features make a project unique to a company, and convert it in a risky undertaking. Projects "aim to accelerate the normal rate of change" in organizations by being the main source of competitive advantage (Nokes \& Kelly, 2007: 17). For this reason, and because they also allow for a more efficient use of resources and lower costs, projects are becoming increasingly vital for companies' survival.

Explicit references to metaphor are infrequent in the project management discipline. Bredillet (2008) provided the most comprehensive overview of different project management schools of thought and the corresponding conceptualizations of the project as a machine, a mirror, a computer, an algorithm, and a billboard. His account, however, lacks a clear explanation for the choice of these metaphors and their conceptual relation with the schools' views of project management. Bredillet's (2008) contribution to the scholarly studies in project management is certainly valuable for the discipline, but his selection of metaphors is not convincingly attested. 
Apart from Bredillet (2008), few other project management scholars have made reference to the use of metaphors in the discipline focusing especially on their heuristic functions. First, Roman (1986) discussed the use of the metaphor of the general systems theory, which was intended to view the project as a whole, constructed from its interdependent parts. Angling (1988) then suggested the metaphor of multiproject environments as the Chinese wall, emphasizing the idea of stability, order and predictability. Packendorff (1995) later proposed the metaphor of the project as a temporary organization, which centered on individuals' actions and their interactions, and which overlaps with Bredillet's (2008) metaphor of the project as a social system. Finally, Eskerod (1996), in response to Angling's (1988) metaphor of the Chinese wall, proposed the metaphor of the Chinese dragon, as it better conveyed the need to adapt to constantly changing multi-project environments. Parallel to this, Eskerod (1996) also suggested that the metaphor of multi-project environments as a zero-sum game could be used to highlight the lack of cooperation and knowledge exchange between different projects.

Indeed, Eskerod (1996) was the only scholar who debated the use of metaphor in project management, responding to Angling's (1988) proposal to view multi-project environments as the building of the Chinese wall. It is important to point out that the Chinese wall and the Chinese dragon metaphors were not motivated by cultural or ideological reasons. The Chinese wall metaphor draws upon common knowledge about the Great Wall of China, a monumental structure, built with precisely placed stones and bricks by thousands of stonemasons over centuries. The Chinese dragon metaphor does not necessarily represent the dragon in Chinese culture (symbol of strength, power, good luck, and control over natural forces), but rather it is just an example of an animal, and was chosen in response to Angling's (1988) metaphor in order to convey completely opposite ideas, such as dynamism, unpredictability, constant change, and adaptation.

The metaphor of the Chinese wall represents multi-project environments or programmes, which Angling (1988: 198) defined as containing "ten, a hundred or a thousand projects", with the basic unit of the programme no longer being a single task or an activity, but rather a self-contained project. Managing a multi-project programme, then, is to effectively plan and supervise each project following specific guidelines.

"To illustrate the point, consider a project such as the construction of the Great Wall in China. Consider the situation immediately prior to construction commencing; there would be spread upon the ground thousands of individual stones awaiting the attention of the stone mason. Collectively, they did not form anything and had no purpose. The stonemason's skill, however, took each stone and placed it in the right position ensuring that it was square and true until the wall was complete. The random heaps of stone were now transformed into a wall and on close inspection each stone can be seen to fulfil a particular purpose, be it a corner or part of the vertical face". (Angling, 1988: 198) 
For Angling (1988), the stones in the wall symbolize single projects when they are managed simultaneously. As each stone must be positioned in the proper place in order to build the wall, so too must each project fulfil a particular function within the programme and be managed according to a precise allocation of resources and timing. Angling (1988) suggests that the metaphor may allow project managers to perceive the need to clearly define their projects' goals and to carefully plan their application.

Eskerod (1996) was interested in the 'management by projects' strategy, rather than in multi-project environments. This strategy was developed in the 1990s as a way to improve companies' product development capabilities, and it emphasized the need to understand multi-project issues. In her paper, Eskerod (1996) questioned the basic aspects of multi-project environments, that is, planning, scheduling and control, based on the assumptions that only stability, predictability, a top-down decision process, etc. ensure success. The metaphor of the Chinese dragon served to critique Angling's (1988) metaphor of the Chinese wall, representing the classic view of multiproject environments: "Companies do not need good stonemasons as much as they need an ability to read the signals that tell them that it is time to change their building style" (Eskerod, 1996: 63). Projects, from this perspective, cannot be conceived as static stones, since the distance between them is neither static nor well-defined.

Eskerod's (1996) metaphor of the Chinese wall arose from Kreiner's (1993) metaphor of the project as a living organism, and it introduces a dynamic perspective and the idea of unpredictability.

"You never know for sure how it [the animal] will behave the next moment. Maybe it will take a step aside, maybe it will bend its neck, while it simultaneously moves its head from side to side to see what is going on in the surroundings and to act upon it. It can move fast, breathe fire and be highly unpredictable. (...) But it seems clear that the more it moves, the more will the muscles, and hereby the projects, change in their relations to each other. Some projects get bigger and more important as others become of less interest. After a short period of time this may change again in a new direction." (Eskerod, 1996: 63)

The Chinese dragon metaphor also reflects the idea of a living system, in which the natural selection of stronger organisms, the extinction of weaker ones, and the battle for sustenance take place. Eskerod (1996) draws upon Darwin's theory of evolution to discuss how projects compete for the necessary human and material resources, how poorly managed projects fail while others are more efficient and thus successful.

\section{Corpus and method}

A corpus of written texts was compiled for this study. Four periodicals targeting project management practitioners ('Project Management Network', 'Project 
Management Today', 'PM World Today', 'Project Perspectives'), along with two project management research journals ('International Journal of Project Management', 'Project Management Journal'), were used to randomly select articles published from 1997 to 2008. The periodicals used are the leading online global project management publications for professionals, while the journals are the two most relevant peerrefereed academic and research publications which address the broad interests of the project management profession. The corpus had 372,304 running words, with 15,036 types and a type/token ratio of 4.12. The corpus contained 146 texts, with 2,550 words on average per text. The corpus statistics were computed with WordSmith Tools 5 (Scott, 2008).

The study followed Philip's (2010) method to identify conceptual metaphors or metaphor themes in specialized corpora, consisting first in studying the corpus frequency lists to identify linguistic metaphor candidates, representing different source domains, and after that, in determining the corpus key words, which indicate possible target domains. According to Philip (2010), the co-occurrence of linguistic metaphor candidates with the corpus key words is symptomatic of the existence of a particular metaphor theme in a text.

The initial stage of this study involved compiling a list of the lexical items from the semantic fields of building and animals, which were used in Angling (1988) and in Eskerod (1996). The corpus of project management texts was electronically queried for those items with WordSmith Tools 5, and a list of concordances was obtained. The list was manually analyzed for metaphorical uses (Pragglejaz Group, 2007). Moreover, the corpus word list was generated to search for other lexical items from the two semantic fields mentioned in the corpus. In order to ensure reliability at this particular stage, the lexical items selected from the word list were checked against Wordnet synsets (http://wordnet.princeton.edu/) and additionally, other items from the two semantic fields given by Wordnet were searched for in the corpus word list. In this way, a complete list of lexical items from the two semantic fields, considered as the metaphor candidates, was produced. After that, the corpus was electronically queried for those metaphor candidates. The resulting concordances were then examined manually, and the actual metaphorical uses were filtered out.

In the second stage of the analysis, the key word list of the corpus was generated with WordSmith Tools 5. A general business corpus of 1,281,834 running words consisting of periodical articles and research papers was used as a reference corpus. The concordances containing building and animal metaphors, identified previously, were then examined for their co-occurrence with the corpus key words. Finally, the frequencies for both the metaphorical uses and for the co-occurrence with the corpus key words were calculated. 


\section{Results and discussion}

The lexical items that Angling (1988) and Eskerod (1996) used to refer to the two metaphors served as the starting point for this analysis. Table 1 shows the normalized frequencies of those items in the corpus.

Table 1. The metaphorical uses of the lexical items from Angling (1988) and Eskerod (1996) in the corpus.

\begin{tabular}{|c|c|c|c|}
\hline $\begin{array}{c}\text { Chinese wall } \\
\text { (Angling) }\end{array}$ & $\begin{array}{c}\text { Normalized frequency } \\
\text { per 1,000 words }\end{array}$ & $\begin{array}{c}\text { Chinese dragon } \\
\text { (Eskerod) }\end{array}$ & $\begin{array}{c}\text { Normalized frequency per } \\
\mathbf{1 , 0 0 0} \text { words }\end{array}$ \\
\hline build & 0.422 & survive & 0.051 \\
\hline construct & 0.097 & eye & 0.043 \\
\hline wall & 0.011 & fight & 0.027 \\
\hline corner & 0.005 & death & 0.013 \\
\hline stone & 0.005 & nurture & 0.011 \\
\hline mason & - & dead & 0.008 \\
\hline stonemason & - & breathe & 0.005 \\
\hline & & creature & - \\
\hline & & die & - \\
\hline & & dragon & - \\
\hline & & muscle & - \\
\hline & & nutrition & - \\
\hline & & organism & \\
\hline
\end{tabular}

Unsurprisingly, lexical items such as 'mason', 'stonemason', 'dragon', and 'creature', explicitly referring to the conceptual metaphors of the Chinese wall and the Chinese dragon were not used with a figurative sense in the corpus. However, other items, not so directly related to the metaphors, such as 'build', 'construct', and 'survive' were used with relevant frequency values of metaphorical meanings. 'Build' and 'construct', for instance, can be related to more general conceptual metaphors such as THEORIES ARE BUILDINGS or IDEAS ARE BUILDINGS (Grady, 1997), which tend to be used across disciplines.

The analysis of the corpus word list resulted in the identification of other lexical items from the semantic fields of building and animals. 46 lexical items from the semantic field of building and 86 from the semantic field of animals were found in the corpus (see Appendix 1). These lexical items were concordanced with WordSmith Tools 5 and analyzed for metaphorical uses. Figures 1 and 2 give the results obtained, including the normalized frequencies. 


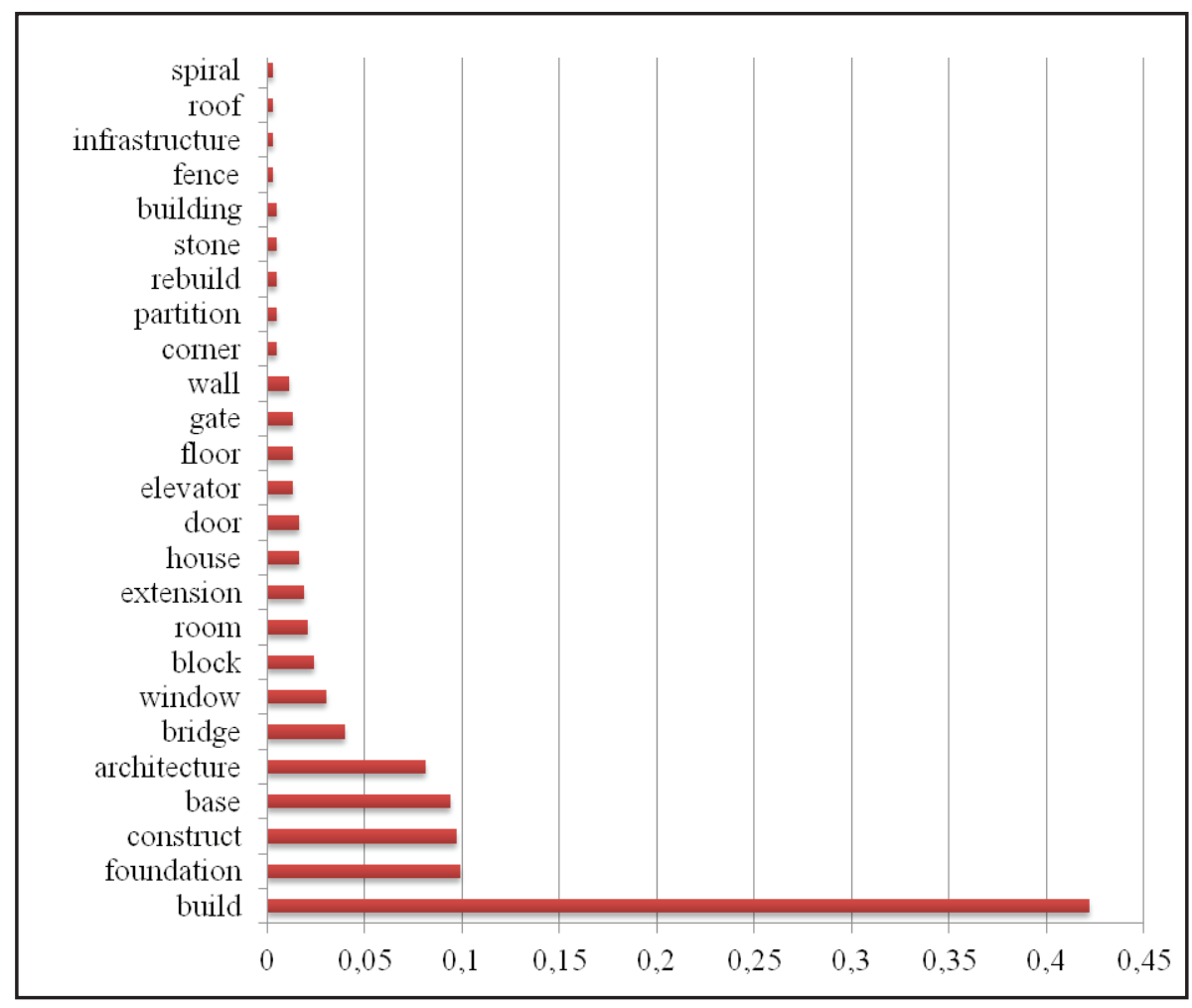

Figure 1. Normalized frequencies (per 1,000 words) of the building metaphor vehicles.

Of the 46 building lexical items from the corpus word list, 25 were used metaphorically. 'Build', 'foundation', 'construct', 'base', and 'architecture' registered the highest frequencies in the corpus (Figure 1). Regarding the animal vehicles, of the 86 lexical items identified in the corpus word list, 55 were used metaphorically: nearly twice as many as the building items. Figure 2 shows the 34 most frequently used metaphor vehicles and their frequencies, while the data concerning the remaining and less frequent metaphor vehicles are included in Appendix 2. In comparison to the building vehicles, more animal vehicles (13) registered significant frequencies (above the average frequency of 0.050): 'grow', 'life', 'agile', 'body', 'health', 'head', 'face', 'neural', 'vital', 'mature', 'lifecycle', 'kill', 'survive'. Only four building vehicles ('build', 'foundation', 'base', 'architecture') were used in this range of frequencies. The data provided here confirm that the building linguistic metaphors are less frequent than the animal linguistic metaphors in the corpus. 


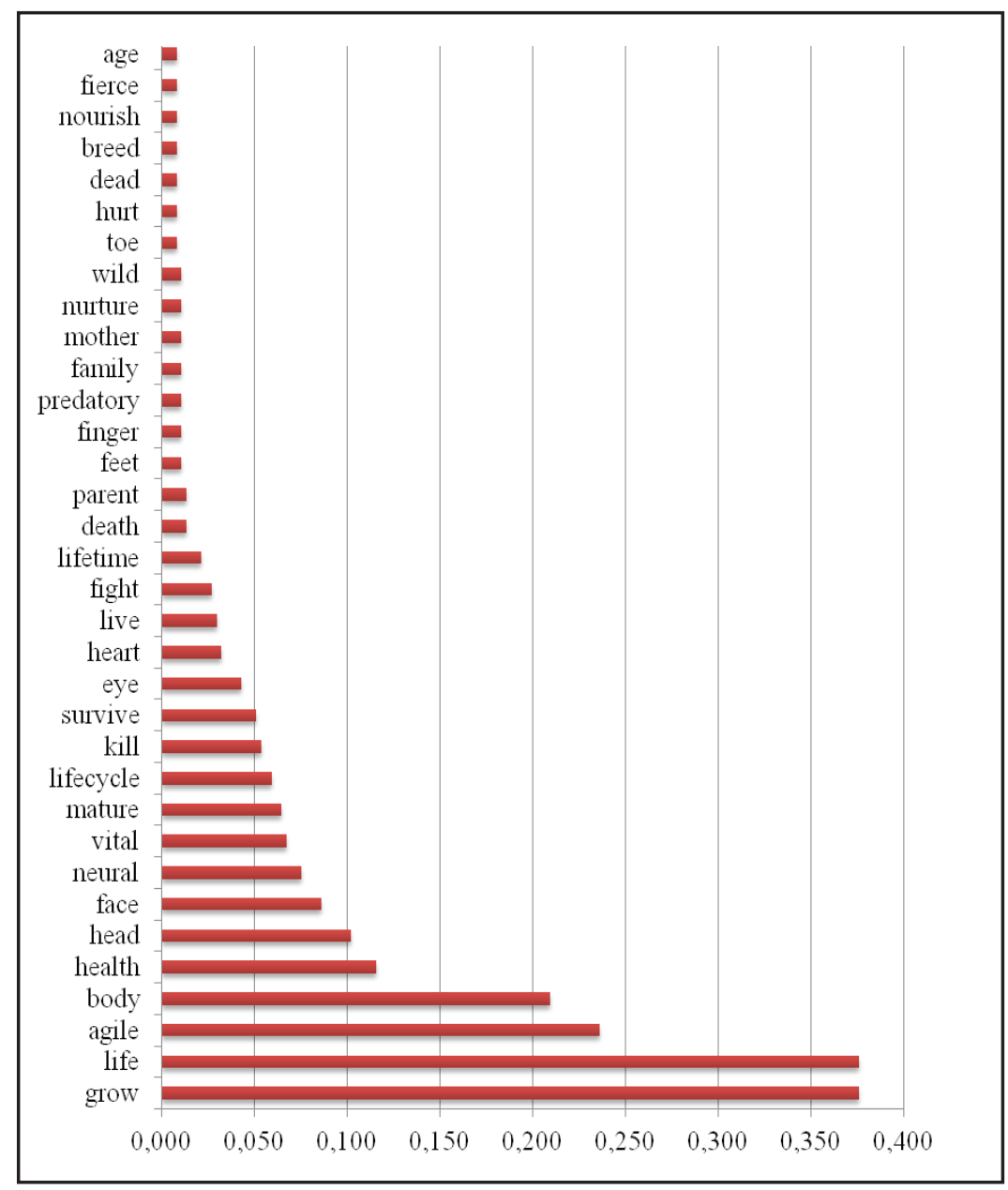

Figure 2. Normalized frequencies (per 1,00o words) of the 34 most frequent animal metaphor vehicles. 


\subsection{The conceptual metaphor of building}

The vehicle frequency data are not always sufficient to determine how pervasive a conceptual metaphor or metaphor theme is in specialized discourse. Identifying the corpus key words and their co-occurrence with the metaphor vehicles provides more reliable evidence in this case (Philip, 2010). For instance, the word combinations of 'build professional excellence' or 'build a solid position on the market' are not indicative of the key metaphorical theme of managing a project as building, since 'excellence' and 'market position' might not be one of the corpus key words. Instead, 'build an organization' or 'build a strategic system' show that the action of building in combination with the corpus key words 'organization' and 'system' creates a relevant key metaphorical theme for this particular discourse.

The key words generated with WordSmith Tools 5 are included in Appendix 3. The data concerning the co-occurrence of the corpus key words with the building are given in Table 2.

Table 2. Building metaphor vehicles co-occurring with the corpus key words.

\begin{tabular}{|c|c|c|}
\hline Metaphor vehicle & $\begin{array}{c}\text { Co-occurrences with key words } \\
\text { (per 1,000 words) }\end{array}$ & $\begin{array}{c}\text { Co-occurrences with key words } \\
\text { (\% of total occurrences) }\end{array}$ \\
\hline build & 0.129 & 30.6 \\
\hline architecture & 0.078 & 96.7 \\
\hline foundation & 0.046 & 45.9 \\
\hline construct & 0.035 & 36.1 \\
\hline block & 0.024 & 100.0 \\
\hline base & 0.016 & 17.1 \\
\hline bridge & 0.016 & 40.0 \\
\hline window & 0.016 & 54.5 \\
\hline extension & 0.013 & 71.4 \\
\hline house & 0.013 & 33.3 \\
\hline room & 0.008 & 60.0 \\
\hline gate & 0.008 & 33.3 \\
\hline door & 0.005 & 50.0 \\
\hline wall & 0.005 & 100.0 \\
\hline partition & 0.005 & 100.0 \\
\hline rebuild & 0.005 & 50.0 \\
\hline stone & 0.003 & 100.0 \\
\hline fence & 0.003 & \\
\hline & & \\
\hline & & \\
\hline & & \\
\hline
\end{tabular}


The building metaphor vehicle co-occurrences with the corpus key words reveal certain frequency variations (Table 2), in comparison to the original frequencies of the building vehicles listed in Figure 1. On the whole, lower values were registered. Seven of the vehicles ('elevator', 'floor', 'infrastructure', 'corner', 'building', 'roof', 'spiral'), which registered low frequencies in the corpus (Figure 1), did not cooccur with the corpus key words. The most frequent vehicles in the corpus (Figure 1: 'build', 'foundation', 'construct', 'base', and 'architecture') varied positions when they were examined for their co-occurrence with the key words. 'Build' remained the first most frequent vehicle, followed by 'architecture', 'foundation', 'construct', 'block', and 'base'. Even though the results are relevant in that they provide evidence of the building metaphor theme in the corpus, the frequency variations detected in the co-occurrence with the corpus key words between the vehicles mentioned are only relatively significant.

The percentage of vehicle co-occurrence with the corpus key words (Table 2), however, shows that certain vehicles consistently combine with the relevant for this discourse words. This consistency indicates that there are stable relations between conceptual and linguistic metaphor patterns. Of the metaphor vehicles with relevant frequencies (i.e. above the average frequency of 0.013), block and 'architecture' were always or nearly always used with the corpus key words, often referring to the parts or the structure of a project management software system (examples 1 and 2) or project management in general (examples 3 and 4).

(1) These major logic 'blocks' perform specific functions that are designed to be foundational functional building blocks of the overall computer system. (Selinger, 2001)

(2) In order to understand how the underlying 'architecture' of OPM3 is modular, it helps to visualize a device that is common in the management of projects: the network diagram. (Schlichter, 2007)

(3) For managerial purposes, however, Gantt activities have to fit a project's building blocks and their dependence relationships, not just DFD dependencies. (Gelbard, Pliskin \& Spiegel, 2002)

(4) The toolsets and processes that complex project management uses to deal with emergence, double loop learning and change, are only effective when the project's strategy and 'architecture' support emergence. (Dombkins, 2008)

'Window', registering a co-occurrence of 54.5\% with the key words, was used with a metaphorically originated terminological sense (Philip, 2010) for a software system element. Thus, its relevance for the building metaphorical theme is questionable. 'Build', the most frequent vehicle co-occurring with the corpus key words, registered a notably low percentage for this type of word combination: $30.6 \%$. 'Build' is a polysemous lexeme, used in highly conventionalized metaphorical expressions in a 
variety of contexts (see 'build knowledge' in example 5). The polysemous metaphoric uses of 'build' could explain why this is the most frequent building vehicle in project management discourse, despite its infrequent co-occurrence with the corpus key words (example 6).

(5) Project management education at the university level and training will help 'build' the necessary knowledge, but it's just beginning to establish itself. (Khor, 2008)

(6) Without these, an organization will not have a strong foundation from which to 'build' skilled project managers, and ultimately will not achieve their better business outcomes. (Prieto, 2008)

Many other, less frequent vehicles, such as 'bridge', 'room', 'house', 'door', 'elevator', 'corner', and 'stone', were used in metaphorically motivated idiomatic expressions, such as 'bridge the gap', 'give room', 'in-house', 'next door', 'elevator speech', 'around the corner' or 'stepping stone', and they did, in most cases, combine with the key words. It is not clear, however, if this type of expressions can be considered as evidence of a particular metaphor theme in the discourse. Their acquired meaning is no longer directly related to the concept of building, and it is questionable whether they are indeed the linguistic manifestation of the metaphorical concept for managing a project as building.

On the whole, there are few building vehicles that show a clear combined patterning with the corpus key words. Other building vehicles represented occasional and nonconsistent uses, or appeared in idiomatic expressions. The findings suggest that even though the linguistic metaphors related to the conceptual metaphor of building are used in the corpus, only a few of them combined with the key words that are relevant for project management discourse. It seems that the metaphor of building, of which Angling's (1988) metaphor of the Great Wall is a concrete example, is not widespread in the case of specialized project management discourse. Understanding project management as building has not provided a powerful and productive perspective, and has not generated significantly recurrent patterns in metaphorical language use.

\subsection{The conceptual metaphor of animal}

Table 3 shows the data related to the co-occurrence of the animal vehicles with the corpus key words. 
Table 3. Animal metaphor vehicles co-occurring with the corpus key words.

\begin{tabular}{|c|c|c|}
\hline Metaphor vehicle & $\begin{array}{l}\text { Co-occurrences with key words } \\
\text { (per } 1,000 \text { words) }\end{array}$ & $\begin{array}{c}\text { Co-occurrences with key words } \\
\text { (\% of total occurrences) }\end{array}$ \\
\hline life & 0.231 & 61.4 \\
\hline agile & 0.196 & 83.0 \\
\hline grow & 0.150 & 38.1 \\
\hline health & 0.110 & 95.3 \\
\hline lifecycle & 0.051 & 86.4 \\
\hline mature & 0.046 & 70.8 \\
\hline survive & 0.040 & 78.9 \\
\hline head & 0.030 & 28.9 \\
\hline neural & 0.030 & 39.3 \\
\hline body & 0.013 & 6.4 \\
\hline heart & 0.013 & 41.7 \\
\hline lifetime & 0.013 & 62.5 \\
\hline parent & 0.013 & 100.0 \\
\hline vital & 0.011 & 16.0 \\
\hline kill & 0.011 & 20.0 \\
\hline fight & 0.011 & 40.0 \\
\hline live & 0.008 & 27.3 \\
\hline nurture & 0.008 & 75.0 \\
\hline toe & 0.008 & 100.0 \\
\hline hurt & 0.008 & 100.0 \\
\hline face & 0.005 & 6.3 \\
\hline mother & 0.005 & 50.0 \\
\hline wild & 0.005 & 50.0 \\
\hline breed & 0.005 & 66.7 \\
\hline pig & 0.005 & 100.0 \\
\hline pregnant & 0.005 & 100.0 \\
\hline eye & 0.003 & 6.3 \\
\hline feet & 0.003 & 25.0 \\
\hline predatory & 0.003 & 25.0 \\
\hline family & 0.003 & 25.0 \\
\hline nourish & 0.003 & 33.3 \\
\hline age & 0.003 & 33.3 \\
\hline breathe & 0.003 & 50.0 \\
\hline $\operatorname{dog}$ & 0.003 & 100.0 \\
\hline monster & 0.003 & 100.0 \\
\hline whale & 0.003 & 100.0 \\
\hline shoulder & 0.003 & 100.0 \\
\hline infancy & 0.003 & 100.0 \\
\hline skittish & 0.003 & 100.0 \\
\hline
\end{tabular}

As with the building vehicles, the frequencies of the animal vehicle co-occurrence with the corpus key words (Table 3) are lower in comparison to their original frequencies as the metaphor vehicles (Figure 2). Fifteen low-frequency vehicles ('death', 'finger', 'dead', 'fierce', 'shark', 'eyeball', 'digest', 'engender', 'elbow', 'skin', 
'wrinkle', 'immaturity', 'longevity', 'young', 'wee') were not combined with the corpus key words. The top-frequency vehicles ('grow', 'life', 'agile') were also the most frequent items co-occurring with the key words, 'life' being the most frequent vehicle combining with the corpus key words.

'Grow' was used in a fashion similar to 'build' regarding its co-occurrence with the corpus key words. Despite being the most frequent metaphor vehicles in the corpus, they did not consistently combine with the corpus key words (see the low percentage of co-occurrence in Tables 2 and 3). Certainly, the two vehicles are significant in the corpus metaphorical material; they registered the highest frequencies both in combination with the corpus key words and in other types of co-text. These data suggest that the two vehicles were used in other metaphorical themes in the corpus, such as THEORIES ARE BUILDINGS or IDEAS ARE BUILDINGS. The identification of metaphor themes through the corpus key words (Philip, 2010) should not mean disregarding those more general themes, as they might be relevant for the description of all metaphorical uses in specialized discourse.

'Agile', 'health', 'lifecycle', 'mature', and 'survive' (Table 3) are high frequency metaphor vehicles, and they were regularly used with the corpus key words, registering from $70 \%$ to $95 \%$ of co-occurrences.

(7) Most people are very familiar with Winston Churchill but may not be familiar with his 'agile' approach to project management and his skills as a PM in the summer of 1940. (Kozak-Holland, 2008)

(8) Then what is changing in the project management? It is the way we manage projects day to day, (...), now there is whirlwind happening in the project management world especially in IT Project Management that is called 'Agile'. So, agile approach is the way of delivering projects. There are many agile development methods. Most of them minimize risk by developing software in a short amount of time, and scrum is one among them. (Jainendrakumar, 2008)

'Agile' on most occasions combines with such key words as 'planning', 'approach', 'project management', 'methodology', 'tool', and 'customers'. Apart from its more general metaphorical meaning that allows for a broad range of combinations with the corpus key words (example 7), agile acquired a terminological sense to describe a particular approach to managing project activities (example 8), in contrast to traditional project management. Agile project management is based on the principle of human interaction management, which views human collaboration as a process. From this perspective, the project becomes a number of tasks designed and completed according to the demands in a changing situation, as opposed to entirely pre-planned actions in traditional project management. In other words, agile project management is applied when the project goal is well defined, but how it will be carried out remains unclear (Wysocki, 2009). In this sense, the adaptability required for complex projects, 
as conveyed by Eskerod's (1996) metaphor of the Chinese dragon, seems to be fully reflected in the metaphorical concept of agile project management.

'Health' was less frequent than 'agile', but it had the highest percentage (95.3\%) of combinations with such corpus key words as 'project', 'program', 'organization', or 'assessment' (examples 9 and 10).

(9) This understanding of project 'health' check is not the same as that by Humphreys et al. [2] or Mian et al. [3]. (Jaafari, 2007)

(10) Program metrics not only measure the 'health' of individual programs, they are also a way to learn about the effectiveness of program management-related domains such as strategic management (...). (Prieto, 2008)

'Lifecycle' (86.4\%) combined most frequently with project in 'project lifecycle', but was also used with program, phase and system (example 11). Mature described organizations, methodology and tools (example 12), while survive was used with reference to project and project manager (example 13).

(11) If emergence is a strategic requirement for the system (particularly emergence over the system's 'lifecycle'), then the systems strategy and architecture must be modular. Modular systems architectures support ongoing emergence. (Dombkins, 2008)

(12) Comparison by maturity level showed that all the tools are being used significantly more in more 'mature' organizations while none are used more in less 'mature' organizations. (Besner \& Hobbs, 2008)

(13) And although it may feel like the end of the world, project managers who actively search for meaning do manage to 'survive'. (Fretty, 2007)

Other metaphor vehicles, such as 'body', 'face' and 'vital', among the first ten most frequent items in the corpus, were rarely used with reference to the key words (around $6 \%$ of co-occurrences), and consequently do not seem to be relevant for the corpus metaphorical theme. The metaphor vehicles with 100\% of co-occurrences ('parent', 'toe', 'hurt', 'pig', 'pregnant', 'dog', 'monster', 'whale', 'shoulder', 'infancy', 'skittish') registered low frequencies, but significantly outnumbered the similar cases for the building metaphorical theme; in this case only three metaphor vehicles combined with the key words.

On the whole, the animal metaphors were not used in metaphorically motivated idiomatic expressions, which were considered irrelevant for the metaphorical theme, as was the case of some building vehicles. However, certain terms consisting of a metaphor vehicle and a key word (e.g. 'agile project management', 'project lifecycle') were used in the animal theme. This suggests that the conceptual metaphor of animal 
might perform a heuristic function. The insights generated by this metaphor might have not only provided novel methodological approaches to project management, such as the agile approach, but also generated expressions that addressed the lack of the non-metaphorical terms in the field.

Clearly, the animal metaphor is more widespread in the case of project management discourse than the building metaphor. Regarding the highest frequency values, the ranges for the animal vehicles combined with the key words were significantly greater than for the building vehicles. Moreover, the total number of the animal vehicles co-occurring with the key words was remarkably higher (39 items) compared to the building vehicles (18 items). The data provided by this study indicate that the animal metaphor is apparently more convenient for managing projects, this being clear on the discourse level as well.

\section{CONCLUSIONS}

The findings of this study confirm that the building and animal conceptual metaphors are reflected in the discourse of project management. The evidence collected also reveals that the animal metaphor or theme is dominant in the corpus in terms of the number of metaphor vehicles identified, their frequencies and their co-occurrence with the corpus key words. It is difficult to state, in view of the data reported, whether one theme is definitely taking over the other, whether they compete or simply complement each other. It is possible that for certain aspects of project management, a particular metaphorical perspective is more appropriate. In this sense, scholars and project management practitioners might favor building expressions with reference to an orderly planning, control, specification of goals, and a precise allocation of resources. On the other hand, the animal metaphors would better express the need for adaptability in the changing environments. A more thorough examination of the word combinations, and their relations to project management concepts, would allow for more conclusive results. The accommodation of metaphorical language for the writer's communicative aims, as is the case of choosing between building and animal metaphors, seems a promising line of research, which would broaden the issues raised in Skorczynska and Deignan (2005) with regard to the choice of metaphors and the readership of economic texts.

A diachronic study of the use of building and animal metaphors could also reveal the evolution of the preferences for one metaphor over the other in a given period of time, while possibly providing insight into the changes in discourse practices under the impact of scholarly publications. A study of Bredillet's (2008) metaphors over time would be suitable for further research in this line.

The corpus data presented in this study also suggest that the evidence for a particular conceptual metaphor or metaphor theme in a sample of specialized corpus necessarily involves both the crystallized combinations resulting in metaphorically 
originated technical terms, as well as other uses of metaphor vehicles and the corpus key words. Metaphor-based terminology is fossilized evidence of the once active cognitive and linguistic processes, similar to highly conventionalized metaphorical expressions. They reveal conceptual associations that are no longer perceived as such by specialists, but can be interpreted as novel metaphors by the non-specialist audience. Even though general discourse may show different patterns of language use in its metaphor themes, as opposed to specialized discourse, research by Ureña and Faber (2010) has revealed that certain conceptual metaphors are especially productive in generating metaphorical terms, which in general are notably frequent.

It is difficult to determine if discourse and its metaphors impact management practices or vice versa. It seems that Angling's (1988) claim for the use of the China Wall metaphor was more prescriptive than Eskerod's (1996) Chinese dragon metaphor, which arose from a field study and thorough observation of real-life project management problems. In this sense, it can be argued that, unlike the Chinese Wall metaphor, the Chinese dragon metaphor reflects the confluence of reality and discourse practices. 


\section{REFERENCES}

Angling, M. (1988). Resource planning and control in multi-project environments. International Journal of Project Management, 6(4), 197-201.

Besner, C. \& Hobbs, B. (2008). A contextual assessment of project management practice: Variation by knowledge area, project type and phase. Project Perspectives, 29, 10-15.

Bicchieri, C. (1989). Should a scientist abstain from metaphor?. In A. Klamer, D. McCloskey. \& R. M. Solow (Eds.), The Consequences of Economic Rhetoric (pp. 100-14). Cambridge: Cambridge University Press.

Boyd, R. (1993). Metaphor and theory change: What is 'metaphor' a metaphor for. In A. Ortony (Ed.), Metaphor and Thought, (pp. 481-532). New York: Cambridge University Press.

Bredillet, C. (2008). Exploring Research in Project management - Nine Schools of Project management Research (Part 6). Project Management Journal, 39(3), 2-5.

Charteris-Black, J. \& Ennis, T. (2001). A comparative study of metaphor in Spanish and English financial reporting. English for Specific Purposes, 20, 249-266.

Charteris-Black, J. \& Musolff. A. (2003). Battered 'hero' or 'innocent victim’? A comparative study of metaphors for euro trading in British and German financial reporting. English for Specific Purposes, 22, 153-76.

Deignan, A. (2005). Metaphor and Corpus Linguistics. Amsterdam: John Benjamins.

Dombkins, D. H. (2008). The Integration of Project Management and Systems Thinking. Project Perspectives, 29, 16-21.

Eskerod, P. (1996). Meaning and action in a multi-project environment. International Journal of Project Management, 14(2), 61-65.

Fretty, P. (2007). The after life. Yes, project managers can survive a botched projectbut they better be ready to apply all those painful lessons learned the next time around. Project Management Network, 21(8), 41-45.

Gelbard, R., Pliskin, N. \& Spiegel, I. (2002). Integrating system analysis and project management tools. International Journal of Project Management, 20(6), 461-468.

Grady, J. (1997). Foundations of Meaning: Primary Metaphors and Primary Scenes. Berkeley: University of California.

Henderson, W. (1994). Metaphor and economics. In R. E. Backhouse (Ed.), New Directions in Economic Methodology (pp. 343-367). London: Routledge. 
Herrera-Soler, H. \& White, M. (2012). Metaphors and Mills. Figurative language in business and economics. Berlin: Mouton de Gruyter.

Jaafari, A. (2007). Project and program diagnostics: A systemic approach. International Journal of Project Management, 25(8), 781-790.

Jainendrakumar, T. D. (2008). Agile - Software Project Management - Scrum methods. PM World Today [online]. Retrieved from: www.pmworldtoday.net/ tips/2008/aug.htm\#2

Kerzner, H. (2004). Advanced Project Management. Hoboken, NJ: John Wiley \& Sons.

Khor, S. K. (2008). The power to transform. Project management is helping Bangladesh change its future. Project Management Network, 22(5), 28.

Kuhn, T. S. (1979). Metaphor in science. In A. Ortony (Ed.), Metaphor and Thought, (pp. 533-42.). New York: Cambridge University Press.

Kozak-Holland, M. (2008). Churchill the Agile Project Manager. PM World Today [online]. Retrieved from: http://www.pmworldtoday.net/featured_ papers/2008/sep.htm

Kreiner, K. (1993). EUREKA - pa dansk. DJØF: Copenhagen.

Nokes, S. \& Kelly, S. (2007). The definitive guide to project management: The fast track to getting the job done on time and on budget. Harlow: Pearson Education Limited.

Packendorff, J. (1995). Inquiring into the temporary organization: New directions for project management research. Scandinavian Journal of Management, 11(4), 319333.

Philip, G. (2010). Metaphorical keyness in specialised corpora. In M. Bondi \& M. Scott (Eds.), Keyness in Texts (pp. 185-203). Amsterdam: John Benjamins.

PMI Standards Committee (2008). A Guide to the Project Management Body of Knowledge. Newtown Square, PA.: Project Management Institute.

Pragglejaz Group (2007). MIP: A method for identifying metaphorically used words in discourse. Metaphor and Symbol, 22(1), 1-39.

Prieto, R. (2008). Evolving Nature of Program Risks in the Engineering \& Construction Industry. PM World Today [online]. Retrieved from: http:// www.pmworldtoday.net/featured_papers/2008/sep.htm

Roman, D. D. (1986). Managing Projects: A Systems Approach. New York: Elsevier Science.

Schlichter, J. (2007). Taking OPM3 to the Next Level. PM World Today [online]. Retrieved from: http://www.pmworldtoday.net/featured_papers/2007/june. thm\#5 
Schumpeter, J. (1954). History of Economic Analysis. New York: Oxford University Press.

Scott, M. (2008). WordSmith Tools 5. Oxford: Oxford University Press.

Selinger, C. (2001). Comparison between hardware system timing and project management critical path analysis methodologies. Project Management Journal, $32(1), 20-28$.

Skorczynska, H. (2010). Metaphor and knowledge specialization: The use of building metaphors in the general business and project management discourse. Proceedings of the 9th AELFE Conference (pp. 1-15). Universität de Hamburg, Germany.

Skorczynska, H. (2012). Metaphor and knowledge specialization in business management: The case of project management discourse. In H. Herrera \& M. White (Eds.), Metaphor and Mills. Figurative Language in Business and Economics (pp. 265-290). Berlin: Mouton de Gruyter.

Skorczynska, H. \& Deignan, A. (2006). Readership and Purpose in the Choice of Economics Metaphors. Metaphor and Symbol, 21(2), 87-104.

Ureña, J. M. \& Faber, P. (2010). Reviewing imagery in resemblance and nonresemblance metaphors. Cognitive Linguistics, 21(1), 123-149.

Wysocki, R. K. (2009). Effective Project Management: Traditional, Agile, Extreme. Indiana: Wiley Publishing, Inc. 


\section{APPENDIX 1}

Lexical items from the corpus word list classified into semantic fields and sub-fields.

\section{Building:}

A) objects: block, bridge, building, fence, greenhouse, hangar, hotel, house, housing, infrastructure, library, ruin; b) parts: arch, base, column, corner, court, door, elevator, extension, floor, foundation; c) activity: architecture, build, construct, construction, masonry, rebuild; d) materials: stone.

\section{Animals:}

A) animals: bird, crocodile, dog, dolphin, fish, fox, horse, monster, pig, seal, shark, snake, whale, zebra; b) body parts: body, brain, cell, elbow, eye, eyeball, eyelid, face, feet, finger, hair, hand, head, heart, organism, palm, shoulder, skin, toe, wrinkle; c) fight: fight, hunt, kill, predatory, survive; d) health: disease, health, hurt, illness, nerve, nervous; e) life processes: age, breed, dead, death, grow, growth, immaturity, infancy, life, lifecycle, live, longevity, mature, mortal, mortem, neural, young, youth, vital; f) physiology: breathe, digest, eat, hunger, wee; g) reproduction: birth, engender, family, female, fertile, hatch, mother, nourish, nurture, parent, pregnant, sterile; h) features: agile, fierce, skittish, wild. 


\section{APPENDIX 2}

The table below lists the normalized frequencies (per 1,000 words) of less frequent animal metaphor vehicles found in the corpus.

\begin{tabular}{|c|c|}
\hline Metaphor vehicle & Frequency \\
\hline pig & 0.005 \\
\hline shark & 0.005 \\
\hline eyeball & 0.005 \\
\hline digest & 0.005 \\
\hline breathe & 0.005 \\
\hline engender & 0.005 \\
\hline pregnant & 0.005 \\
\hline $\operatorname{dog}$ & 0.003 \\
\hline monster & 0.003 \\
\hline whale & 0.003 \\
\hline elbow & 0.003 \\
\hline shoulder & 0.003 \\
\hline skin & 0.003 \\
\hline wrinkle & 0.003 \\
\hline immaturity & 0.003 \\
\hline infancy & 0.003 \\
\hline longevity & 0.003 \\
\hline young & 0.003 \\
\hline wee & 0.003 \\
\hline skittish & 0.003 \\
\hline
\end{tabular}

\section{APPENDIX 3}

The corpus key words classified into semantic sub-fields of project management:

a) implementation: assessment, communication, complex, complexity, construction, delivery, development, execution, goals, implementation, management, phase, PPP, practice, process, processes, program, programs, project, requirements, resources, risk, success, tool, tools, work; b) methodology: approach, EVM, methodology, planning, portfolio, PPM, schedule, system, scope; c) people: client, contractor, experience, manager, PMP, stakeholders, team, training; d) organization: organizations, organizational, organization, PMO; e) institutions: PMI; f) countries: USA. 